УДК 339.138

JEL classification: M39

Чайка Є.В.

ORCID ID: 0000-0003-4799-5634

Зозульов $\boldsymbol{O} . \boldsymbol{B}$.

канд. економ. наук, професор

ORCIDID: 0000-0001-7087-2080

Начіональний технічний університет Украйни «Киїський політехнічний інститут імені Ігоря Сікорського»

\title{
СУБ'ЄКТИ РИНКУ КІБЕРСПОРТУ ТА ВІДНОСИНИ МІЖ НИМИ
}

\section{THE ESPORTS MARKET SUBJECTS AND RELATIONS BETWEEN THEM}

Визначено сутність ринку кіберспорту, встановлено його місце в системі економічних відносин. Запропоновано і охарактеризовано його структуру. Окреслено роль кожного із учасників ринку кіберспорту, зокрема: розробників ігор, організаторів змагань, гравців, уболівальників, клубів, стрімінгових компаній, засобів масової інформації, спонсорів. Виявлено основні джерела формування прибутку кожного із суб'єктів ринку. Встановлено, щзо всі учасники, реалізуючи власні інтереси, активно взаємодіють між собою $і$ забезпечують розвиток ринку. Виявлено активний ріст ринку, доведено, щзо на даний час основна причина росту - вкладення інвесторів і спонсорів. На основі изього визначено низький рівень окупності, але значний економічний потениіал перспективного характеру $і$ наголошено на проблемі незбалансованого фінансування. Подано структуру найбільших учасників ринку, його регіональну структуру в глобальних масштабах. Наголошено на провідній ролі Китаю та США в розвитку індустрії кіберспорту. Проаналізовано споживчі характеристики ринку за дисииплінами $i$ статево-віковою структурою.

Ключові слова: маркетинг, кіберспорт, відеогра, маркетинг на ринку кіберспорту, суб’єкти ринку кіберспорту.

The article determines the essence of the esports market and establishes its structure and place in the system of economic relations. Particular attention is devoted to defining the role of each market participant: game developers, competition organizers, players, fans, clubs, streaming companies, media, sponsors, and identifying their main sources of income generation. It is ascertained that all participants, while pursuing their own interests, actively interact with one another to ensure market development. Strong market growth is reported and it is proved that the current key drivers are investors and sponsors, indicating a low ROI with significant economic potential, and outlining an inequitable funding model. This work provides a structure of the largest market players and its regional segmentation on a worldwide scale, stressing the leading roles of China and the USA in the development of the esports industry and presents a detailed analysis of the consumer characteristics by titles and gender and age structure.

Keywords: marketing, esports, video game, marketing of esports market, the esports market subjects.

Вступ. В сучасному світі інформаційні технології займають важливе місце. Вони використовуються практично у всіх сферах життя, починаючи від автоматизації рутинних операцій, закінчуючи управлінням космічними 
польотами. В різних сферах економічного життя IT-розробки дозволяють економити ресурси, покращувати контроль та управління, формувати додану вартість і підвищувати фінансові показники компаній. Проте, існують цілі галузі, в яких вони відіграють не допоміжну, а ключову і системоутворюючу роль. Однією із таких сфер є кіберспорт.

Кіберспорт перебуває на стику індустрії розваг, IT-сфери і спорту. Він володіє всіма ознаками, характерними для цих сфер: великим попитом в певної категорії споживачів; високим рівнем інформатизації та змагальною складовою. Окрім цього, він наділений ознаками ринку як економічної категорії, зокрема: заснований на товарних відносинах; передбачає активну взаємодіє різних зацікавлених осіб; має конкурентний характер.

Стан розвитку кіберспорту з позиції ринкових відносин на сьогодні $\epsilon$ малодослідженим. В українському суспільстві досі точаться дискусії щодо його офіційного статусу, впливу відеоігр на здоров'я підлітків, а також економічного потенціалу. Так, на відміну від багатьох країн світу (Китай, США, Південна Корея, Франція, Німеччина, Швеція та ін.), в Україні кіберспорт досі не включений до офіційних видів спорту [6]. Окрім цього, його функціонування в країні не регулюється жодними спеціальними нормативними актами. Тим не менш, на відміну від багатьох традиційних видів спорту, наші кіберспортсмени мають найвищі нагороди у багатьох дисциплінах, а обсяг ринку відеоігр щороку зростає.

Зважаючи на достатньо «молодий вік» кіберспорту, глибина його наукового вивчення в контексті елемента ринкової економіки $є$ досить незначною. Серед найбільш комплексних i грунтовних праць в цьому контексті відмітимо роботи вітчизняних вчених: І. Лазнева і Д. Царенко [4], а також ряду зарубіжних дослідників: С. Хантера (S. Hunter) [11]; Б. Каннінема (B. Cunninghem) [8], Л. Вайсмена (L. Wiseman) [12] та ін. В більшості, згадані автори оцінюють стан і перспективи розвитку ринку, досліджують його структуру та особливості. Тим не менш, питання взаємодії суб'єктів ринку кіберспорту залишаються недостатньо розкритими i потребують більш глибокого і комплексного вивчення.

Постановка завдання. Метою дослідження $\epsilon$ аналіз функціонування ринку кіберспорту з позиції його суб'єктів, що передбачає визначення їх складу, систематизацію інтересів, взаємозв'язків та обгрунтування потенціалу.

Методологія. Методологію дослідження та ii теоретичну основу становлять методи емпіричного пізнання: індукція, дедукція, спостереження, оцінка, перевірка та порівняння. Інформаційні джерела - аналітичні публікації та звіти, Інтернет-ресурси та публікації в наукових виданнях.

Результати дослідження. Згідно звіту NewZoo (провідної аналітичної компанії у сфері кіберспорту), розмір світового ринку кіберспорту в 2019 р. сягне 152,1 млрд. дол. До 2022 р. очікується його збільшення ще на 28,9 \% до рівня 196,1 млрд. дол. [9]. Такі темпи приросту свідчать про високий економічний потенціал ринку і обумовлюють актуальність його вивчення [7]. 
Економічне пізнання ринкових процесів потребує чіткого розуміння предмету дослідження. Відповідно до цього, при визначенні ключових термінів використаємо відомі трактування. Так, згідно визначення В. Іванова, Д. Нікіфорова і О.Коршунова, «кіберспорт (відомий в багатьох країнах як eSports - від англ. «електронний спорт») - це змагання з використанням комп'ютерних технологій, де ЕОМ $\epsilon$ засобом змагання, що моделює віртуальний простір, всередині якого відбувається боротьба» [2]. Відповідно до цього, ринок кіберспорту може трактуватися як система економічних відносин 3 приводу купівлі, продажу, використання та обслуговування продукції IT сфери у формі відеоігор та пов'язаних із ними елементів.

Деталізуючи запропоноване трактування визначимо ринок кіберспорту має складну структуру, яка відображає його елементний склад. Так, С. Хантер виділив такі основні суб'єкти ринку (рисунок).

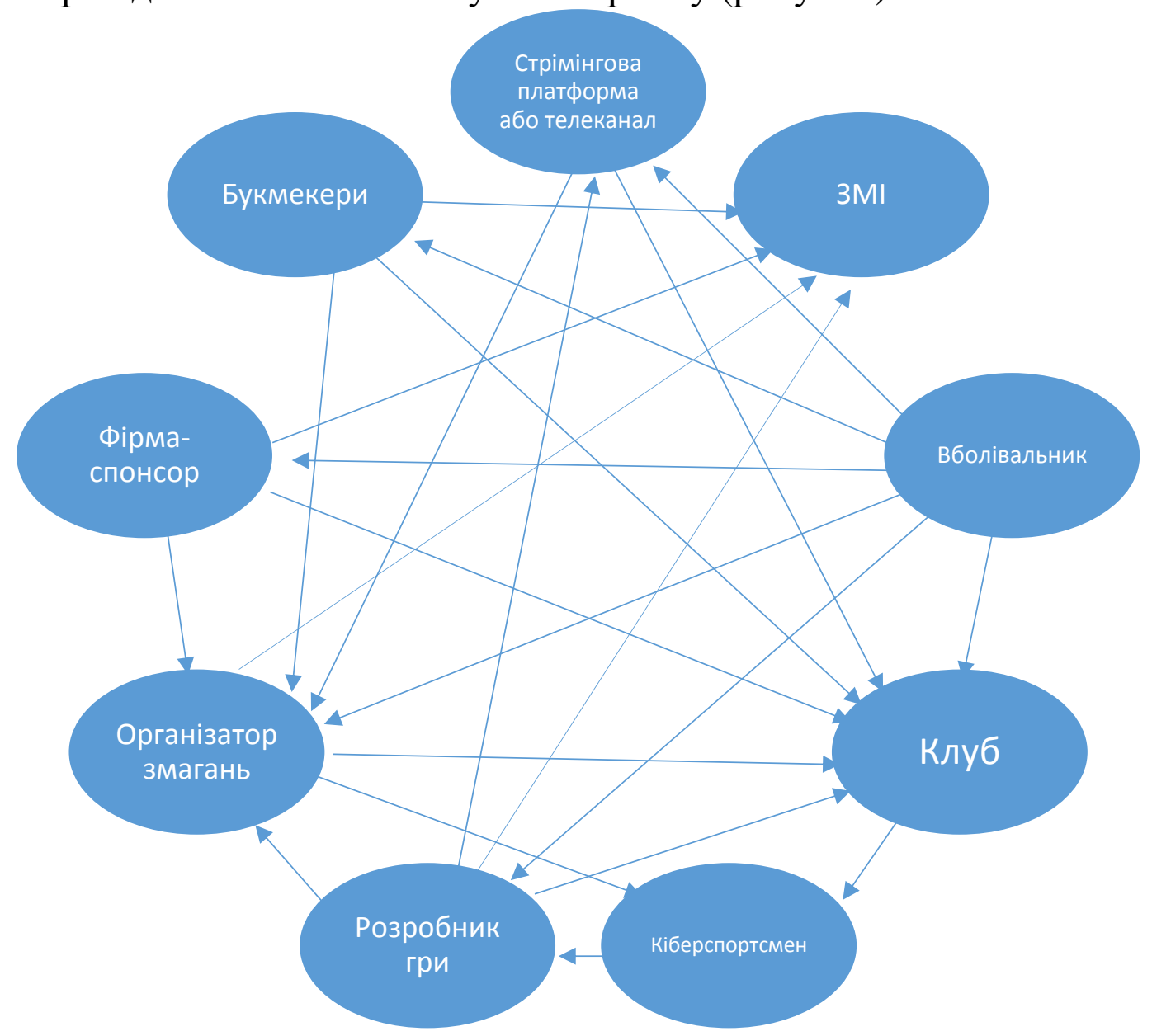

Рисунок - Зв’язки між суб’єктами ринку кіберспорту.

Кожен із поданих суб'єктів має власну роль у системі взаємовідносин, що формуються навколо його інтересів. Так, С. Хантер зазначає, що кожен суб'єкт пропонує свій «товар»: розробник гри - пропонує відеогру; кіберспортсмен - власні вміння і навики; кіберспортивний клуб - рекламні ліцензії та право на використання атрибутики; організатори змагань - умови для проведення ігор і спостерігання за ними; стрімінгові платформи - 
можливість перегляду змагань і тренувань; студії коментувань - оперативне висвітлення змагань; ЗМІ - медіа підтримку змагань та проектів [11].

За рахунок цього, кожен суб'єкт задовольняє визначену специфічну потребу інших учасників ринку, отримуючи взамін фінансову винагороду чи інші вигоди.

Ключовою ланкою в кіберспорті є розробник гри. Він створює гру зі змагальною складовою, спонсорує відомі клуби, замовляє організацію турнірів та рекламу на стрімінгових платформах і телеканалах. Прибуток надходить від кіберспортсменів та вболівальників, внаслідок покупки гри, внутрішньо ігрової валюти та сезонних доповнень. Розробники зазвичай не організовують турніри і не володіють клубами, але саме від них залежать умови ігрового процесу. За даними NewZoo в 2018 р. десять розробників ігор сумарно отримали майже $56 \%$ виручки ринку. Лідером при цьому залишилася китайська компанія Tancent, власник Riot Games i найпопулярнішої ліги League of Legends (13\%), а також японська Sony $(9,3 \%)$ (таблиця 1$)$.

Таблиця 1- 10 найбільших розробників відеоігор в світі за даними 2018 p. [9]

\begin{tabular}{|l|l|c|c|}
\hline № & \multicolumn{1}{|c|}{ Компанія - розробник } & $\begin{array}{c}\text { Виручка, млрд. } \\
\text { дол. }\end{array}$ & $\begin{array}{c}\text { Річний } \\
\text { приріст, \% }\end{array}$ \\
\hline 1 & Tancent & 19,7 & 9 \\
\hline 2 & Sony & 14,2 & 41 \\
\hline 3 & Microsoft & 9,8 & 32 \\
\hline 4 & Apple & 9,4 & 18 \\
\hline 5 & Activizion Blizzard & 6,9 & 6 \\
\hline 6 & Google & 6,5 & 22 \\
\hline 7 & Netease & 6,2 & 11 \\
\hline 8 & EA & 5,3 & 4 \\
\hline 9 & Nintendo & 4,3 & 36 \\
\hline 10 & Bandai Namco & 2,7 & 13 \\
\hline
\end{tabular}

Популярність Тancent в значній мірі обумовлена іiі політикою щодо підтримки гравців. Учасники League of Legends отримують від компаніï розробника найпрофесійнішу фінансову підтримку в кіберспорті. Їм оплачується проживання, послуги тренерів та інших фахівців, забезпечується безкоштовне проживання та харчування.

Звязуючою ланкою між розробниками i гравцями виступають організатори змагань. Вони забезпечують умови для проведення змагань на базі визначеної гри. Організатор змагань виплачує призові клубу та кібеспортсменам за рахунок ексклюзивності стрімінгової платформи, продажу квитків, реклами гри, брендів та букмекерів. Найбільш рейтинговими змаганнями $є$ міжнародні турніри. Вони збирають гравців 3 усього світу, проте в залежності від місця проведення вони мають регіональну специфіку. Відповідно до цього вплив організаторів фокусується в межах географічного регіону, наприклад: в Північній Америці найбільшим 
впливом володіють ELEAGUE і MLG; в Західній Європі - Dreamhack, Electronic Sports League, Faceit, PGL; в Східній Європі - київський StarLadder і московський Epicenter; в Азії - WESG и I-League.

В контексті зазначеного відмітимо, що регіональний розподіл ринку $\epsilon$ досить нерівномірним і залежить від ступеня розвитку інтернет-культури країн. Так, найбільшим ринком в світі кіберспорту є азійський, який разом із Австралією та Океанією приносить 72,2 млрд. дол прибутку (47, 5 \% ринку). Другим за розміром є ринок Північної Америки - (39,6 млрд. дол). Далі йдуть ринки Західної Свропи (25,7 млрд. дол), Латинської Америки (5,6 млрд. дол), Африки та Близького Сходу $(4,8)$ і Східної Свропи (4,2 млрд. дол). Розмір українського ринку в 2019 р. складе 203 млн. дол. (0,13% світового показника) [9].

Ключовими суб'єктами ринку кіберспорту є гравці. Саме для них розробляються ігри, вони виступають найактивнішими учасниками i головними покупцями. По своїй економічній природі вони одночасно виступають споживачами продукції при покупці відеігор, а також агентами галузі у випадку публічної ігрової діяльності. В другому випадку, гравець виступає популяризатором гри. Завдяки участі у змаганнях i їх публічному висвітленні відбувається ключове поширення інформації про ігри.

Кібергравці мають професійний або аматорський статус. В першому випадку вони працюють на клуби, отримують заробітну плату та призові на змаганнях. Професійні гравці не мають привілеїв перед рядовими гравцями. Тому вони, як і вболівальники, є покупцями гри та іiі доповнень. Професійні гравці в кіберспорті є досить високооплачуваними. Їхня зарплата становить від 5 до 20 тис. доларів в залежності від регіону і популярності дисципліни, в якій вони виступають.

По аналогії із традиційними видами спорту кібергравці тренуються, дотримуються спеціальних дієт i розпорядку дня. Окрім того, вони підписують контракт із клубом, відповідно до якого визначаються взаємовідносини між ними. Як і у традиційних видах спорту, кібергравці можуть змінювати клуб. В окремих випадках вони можуть переходити в інші клуби за досить велику суму.

Загальна кількість кібергравців у світі в 2019 році склала 2,5 млрд. осіб. Їх найбільша кількість була зосереджена в Азї та тихоокеанському регіоні 1331,2 млн. осіб (53 \%). В країнах Африки та Близького Сходу було зосереджено 359,5 млн. осіб (14,3 \%), В Латинській Америці - 252,6 млн. осіб (10,1 \%), в Північній Америці - 197,6 млн. осіб, в Західній Свропі - 215,6 млн. осіб, в Східній Європі - 155,6 млн. осіб.

Особливістю цієї категорії суб’єктів є те, що ії найбільш активна частина - це молоді чоловіки у віці 16-20 років. Їхній демографічний аналіз показує, що ця аудиторія має високий рівень купівельної спроможності, яка обчислюється мільярдами доларів, але вони $\epsilon$ досить інертними до маркетингових сигналів. Окрім цього, гравці $є$ досить неоднорідними за своїми вподобаннями. Так, найбільше із них - 400 млн. осіб віддають 
перевагу дисципліні Fornite. Близькою до цієї цифри є кількість гравців у League of Legends - 380 млн. осіб. Загальний розподіл гравців серед найбільш популярних ігор подано в таблиці 2.

Таблиця 2 - Статистика кількості гравців кіберспортивних дисциплін в 2018 p. [7]

\begin{tabular}{|l|l|c|c|c|}
\hline № & \multicolumn{1}{|c|}{ Дисципліна } & $\begin{array}{c}\text { Загальна } \\
\text { кількість } \\
\text { гравців, млн. } \\
\text { осіб }\end{array}$ & $\begin{array}{c}\text { Щомісячна } \\
\text { кількість } \\
\text { гравців, млн. } \\
\text { осіб }\end{array}$ & $\begin{array}{c}\text { Стала } \\
\text { аудиторія, \% }\end{array}$ \\
\hline 1 & Fortnite & 400 & 125 & 31 \\
\hline 2 & League of Legends & 380 & 100 & 26 \\
\hline 3 & PlayerUnknown's Battlegrounds & 326 & 80 & 25 \\
\hline 4 & Dota 2 & 102 & 19 & 19 \\
\hline 5 & Counter-Strike: Global Offensive & 35 & 14 & 40 \\
\hline 6 & Overwatch & 30 & 14 & 47 \\
\hline 7 & Hearthstone & 70 & 12 & 17 \\
\hline 8 & Heroes of the Storm & 20 & 10 & 50 \\
\hline 9 & StarCraft 2 & 15 & 10 & 67 \\
\hline 10 & FIFA & 14 & 8 & 57 \\
\hline
\end{tabular}

Як бачимо, тільки чотири дисципліни охоплюють більше 100 млн. гравців. При цьому, стала аудиторія жодної із них не перевищує $31 \%$. На відміну від них, серед решти поданих в таблиці 2 дисциплін, тільки Hearthstone має сталу аудиторію, меншу за 40 \%. Найбільша стала аудиторія - y StarCraft $2-67 \%$ гравців.

Окрім гравців, споживачем продукції кіберспорту виступають уболівальники. Вони купують ігри, білети на змагання, атрибутику клубів та підписку на стрімінговий контент. Вони можуть бути клієнтами брендівспонсорів кіберспорту та букмекерських контор. В 2018 році загальна аудиторія глядачів кіберспортивних змагань склала 385 млн. осіб. 3 них, 191 млн - це вболівальники, які мають глибоке розуміння суті гри, а 194 млн осіб - випадкові глядачі, які не в повній мірі розуміють сутність кіберспортивних дисциплін, але цікавляться ними. Цікаво, що в гендерному розрізі основну аудиторію складають чоловіки - $71 \%$. 3 них, 52 \% - це люди у віці 21-35 років. $27 \%$ аудиторії - це підлітки віком 10-20 років.

Демографічний поділ глядачів і його динаміка свідчать про підвищення економічного потенціалу ринку кіберспорту, оскільки кількість його прибічників поступово зростає за рахунок молодого покоління чоловіків. Це означає, що купівельна спроможність споживачів збільшується і це позитивно впливає на ріст ринку.

Клуби як суб'єкти ринку кіберспорту займаються менеджментом кіберспортсменів. Їх прибуток формують надходження від: спонсорівбрендів, компенсації від розробників гри, проценту від призових на змаганнях, продажів фанатського мерчендайзу, реклами букмекерів, ексклюзивних стрімінгових платформ. 
Клуби об’єднують гравців і частину глядачів. Вони діють в їх інтересах, а також в інтересах розробників ігор, спонсорів, трансляторів тощо. По суті, головна продукція клубів - це не стільки можливість зіграти у гру, скільки можливість отримати емоції від спільних дій. Головне завдання клубу створити стійкий зв'язок між розробниками ігор, гравцями, фанатами, глядачами, спонсорами та іншими учасниками. Серед українських кіберспортивних клубів найбільш відомий - Natus Vincere (3 лат. Народжені перемагати). Він був заснований у 2009 році і протягом декількох років перемагав у найпопулярніших у Східній Свропі дисциплінах - CS i DOTA.

Стрімінгові платформи та телеканали капіталізуються шляхом продажу вболівальникам підписки, просування нових ігор від розробника та вбудованої реклами. Лідером в даному сегменті ще з 2011 року $\epsilon$ Twitch.tv. Компанія завоювала свою популярність завдяки безкоштовним трансляціям і спрощеному доступу до перегляду кіберспортивних змагань. Платформа сформувалася на демократичному принципу, який урівнював права турнірів із багатомільйонним призовим фондом i особисту домашню трансляцію. Розвиток і доступність цифрових технологій дозволили акумулювати на одному ресурси всі головні події у світі кіберспорту. Основне джерело доходів стрімінгових компаній - плата за підписки. Вона дозволяє отримувати доступ до ексклюзивного контенту, переваг у спілкуванні і забезпечує можливість відключення реклами.

Поряд із стрімінговими компаніями важлива роль у висвітленні подій і популяризації кіберспорту відводиться ЗМІ. Кіберспортивні засоби масової інформації монетизують свій контент за рахунок реклами відомих брендів та букмекерських контор. Вони взаємодіють із усіма учасниками ринку i забезпечують їх інформування про події в світі кіберспорту.

Спортивна складова кіберспорту і високий рівень його популярності обумовив роботу на цьому ринку таких інструментів, як букмекери. Ці суб'єкти ринку виявилися досить успішними для того, щоб заробляти, як на глядачах, так і на інвесторах. Вони дозволяють глядачам робити ставки на перемогу котроїсь із команд. При цьому, на основі ймовірності настання певного результату букмекери визначають котирування подій, а азартні глядачі роблять ставку на визначений результат. Популярні світові букмекерські контори уже тривалий час приймають ставки на такі дисципліни як: League of Legends, DOTA 2, CS:GO, Overwatch i StarCraft.

Окрім гравців і уболівальників, важливим суб'єктом, що забезпечує надходження фінансових ресурсів на ринок кіберспорту є фірми-спонсори. Вони інвестують в кіберспортивні клуби та турнірних операторів. Також вони замовляють статті в ЗМI, за рахунок чого налагоджують комунікацію 3 лояльною до реклами аудиторією. В кіберспорті спонсорство може стосуватися або організації турніру, або ж гравців чи їх команд. В першому випадку спонсорство проявляється через постачання напоїв, використання визначеного набору техніки, інформування про роботу букмекерів. В 
другому - у розміщенні логотипів на формі, використанні гравцями гарнітур гарнітур, поведенні промо кампаній.

Відмітимо, що частка інвестицій та спонсорських внесків у структурі доходів кіберспорту на сьогодні становить близько 30 \%. Це дозволяє ідентифікувати ринок як доволі нестабільний із слабкою окупністю. Тому, 3 метою стабілізації доходів, необхідно поступово перетворювати кіберспортивні заходи на високодохідні події.

Таким чином, головні суб'єкти ринку кіберспорту активно взаємодіють між собою. Реалізуючи власні інтереси, вони тим самим забезпечують потреби інших учасників i сприяють розвитку галузі. Виходячи із українських реалій, для покращення взаємодії між ними необхідно вжити декілька заходів, спроможних врегулювати окремі аспекти взаємодії та підвищити економічний потенціал. В першу чергу це стосується прийняття нормативного акту для законодавчого регулювання таких відносин.

Висновки. Ринок кіберспорту утворюють його суб'єкти, які взаємодіють між собою $\mathrm{i}$, в результаті цього, забезпечують його функціонування. Головними учасниками ринку є розробники ігор, клуби та кіберспортсмени, організатори змагань, стрімінгові платформи та ЗMI, вболівальники та гравці, спонсори і букмекери. В сукупності вони утворюють цілісну систему, яка підпорядковується ринковим законам. Споживачами послуг на ринку виступають гравці та глядачі. Вони купують саму гру або право спостерігати за нею. Ці процеси відбуваються через клуби та організаторів турнірів, за посередництвом ЗМІ або стрімінгових платформ. На жаль, в сукупності зазначені суб'єкти не можуть забезпечити повноцінного функціонування ринку та його розвитку. Відповідно до цього, економічна модель кіберспорту на даний час працює завдяки коштам інвесторів, спонсорів та букмекерів.

Дослідження суб'єктів ринку кіберспорту і відносин між ними є досить складним завданням, яке є дотичним до інших сфер людської діяльності. Відповідно до цього, подальші дослідження стосуватимуться детального вивчення кожного із суб'єктів ринку, а також тих секторів, економіки, які найбільш тісно взаємодіють із суб' єктами ринку кіберспорту.

\section{Література:}

1. Буянова А.В., Козилина В. Киберспорт : История становления, современное состояние и перспективы развития. Социально-политические науки. 2017. №5. URL: https://cyberleninka.ru/article/n/kibersport-istoriya-stanovleniya-sovremennoe-sostoyanie-iperspektivy-razvitiya. (дата звернення: 20.08.2019).

2. Иванов В., Никифоров Д., Коршунов А. Киберспорт: экономические и юридические аспекты развития. Pedagogical experience: theory, techniques and practice : материалы VII Междунар. науч.-практ. конф. (Cheboksary, May 15, 2016) / editorial board: O.N. Shirokov [etc.]. Cheboksary: SCC "Interaktiv plus", LLC, 2016. pp. 188-193.

3. Коваленко С.В. Основні етапи інформатизації суспільства та освіти. Вісник Чернігівського начіонального педагогічного університету. Серія: Педагогічні науки. 2016. Вип. 135. С. 181-184. URL: http://nbuv.gov.ua/UJRN/VchdpuP_2016_135_47. (дата звернення: 12.08.2019). 
4. Лазнева I. О., Цараненко Д. І. Кіберспорт та його вплив на зміну структури світового ринку комп'ютерних ігор. Науковий вісник Ужгородського національного університету. Випуск 22, частина 2. 2018. С. 3-67

5. Лисенко Т., Морозова О. Ознаки кіберспорту як спортивної дисципліни. Науково-методичні основи використання інформаційних технологій в галузі фізичної культури та спорту : збірник наукових пращь. Харків : ХДАФК, 2019. Випуск 3. С. 63-67.

6. Про затвердження Реєстру визнаних видів спорту в Україні Наказ Міністерства молоді та спорту України (№ 639 від 11.03.2015). URL: https://zakon.rada.gov.ua/rada/show/v0639728-15. (дата звернення: 12.08.2019).

7. Чайка Є.В. Стан та динаміка росту ринку кіберспорту. Економічний вісник Національного технічного університету України «Київський політехнічний інститут». 2018. № 15. C. 443-452.

8. Cunningham B.. Why eSports Is The Next Big Thing In Marketing? URL: https://www.forbes.com/sites/baldwincunningham/2016/02/25/why-esports-is-the-next-bigthing-in-marketing/. (дата звернення: 10.08.2019).

9. Global Game Market Report (Free version). NewZoo. 2019. URL: https://newzoo.com/insights/trend-reports/newzoo-global-esports-market-report-2019-lightversion/. (дата звернення: 10.08.2019).

10. Greenfield P.M. The Cultural Evolution of IQ. The Rising Curve. Long-TermGainsin IQ and related Measures. Washington. 1998. P. 81-123.

11. Hunter S. Digital Natives: The Rise of Esport. URL: https://www.parksassociates.com/bento/shop/samples/Parks\%20Assoc\%20Digital\%20Natives\% 20Rise\%20of\%20Esports\%20TOC.pdf. (дата звернення: 08.08.2019).

12. Wiseman L. The future of esports marketing. URL: https://venturebeat.com/2017/11/09/the-future-of-esports-marketing-2/. (дата звернення: 08.08.2019).

\section{МАРКЕТИНГОВИЙ РОЗПОДІЛ ІННОВАЦЙНОЇ ПРОДУКЦІї ВИСОКОТЕХНОЛОГІЧНИХ ПІДПРИЕМСТВ НА ОСНОВІ ВІРТУАЛЬНОГО ЗАБЕЗПЕЧЕННЯ ТА ЕКОЛОГІСТИКИ}

\section{THE MARKETING DISTRIBUTION OF HIGH-TECH ENTERPRISES INNOVATIVE PRODUCTS OF BASED ON VIRTUAL PROVIDING AND ECOLOGISTICS}

Стаття присвячена уточненню і поглибленню розуміння сутності інтеграційної взаємодії маркетингу $і$ логістики в концепційній системі маркетингового просування інноваційної продукції з урахуванням зелених $i$ віртуальних інформаційних аспектів формування логістичної системи високотехнологічних підприємств України. Удосконалено маркетингову ичіннісну процедуру поліканального розподілу інноваційної продукиіі високотехнологічних підприємств на основі віртуального забезпечення екологістики. Комплексне застосування концепиії екологістики дозволяє досягти всеосяжного забезпечення комфортної, чистої $i$ безпечної взаємодії із навколишнім 